\title{
THE POSITION OF JUDICIAL OVERSIGHT OF JUDICIAL INDEPENDENCE IN CONTEMPORARY LEGAL SYSTEMS
}

Gholamreza Jalali ${ }^{1}$

Seyyed Vahid Lajevardi ${ }^{2}$

Abbas Ali Heydari ${ }^{3}$

\begin{abstract}
In the political systems of nations, independence from the political pressure exerted by government officials and legislators guarantees the impartiality of judges. Thus, the power of judges to review public law and to violate the constitution by them acts as a fundamental obstacle to the possible abuse of power by the state. This power

therefore, on judicial independence in this sense must, to some extent, be that the balance of power is maintained. Just as judges in the United States and England are elected by political bodies such as the President and the Senate, there must be a way for the judiciary to maintain the balance of power, which is nothing but judicial oversight.
\end{abstract} requires the courts to be independent and able to make their decisions based on the law. Administrative and institutional independence of the judiciary has never been a matter of purpose and has not been an inherent matter, but has been a means of securing the independence of the judge. Because the mere organizational and organizational independence of the judiciary is as valid as the independence of the legislature and the executive. The emphasis,

Keyword: Judicial independence, separation of powers, judicial oversight

\section{Introduction}

Judicial autonomy is when judges are judged solely on the basis of their legal standards and the guidance of their conscience without any outside or internal influence. The judge should not be afraid of any obstacles and should not be deterred by fear of dismissal,

\footnotetext{
${ }^{1} \mathrm{PhD}$ Student in Private Law, Arak Branch, Islamic Azad University, Arak, Iran.

${ }^{2}$ Assistant Professor, Department of Private Law, Arak Branch, Islamic Azad University, Arak, Iran. (Corresponding Author)

${ }^{3}$ Assistant Professor, Department of Jurisprudence and Law, Arak Branch, Islamic Azad

University, Arak, Iran
} 
degradation, and change of employment and position. Judicial autonomy has a general meaning and is the same for all officials, so judicial independence from the executive, the representatives of the judiciary, the judiciary and law enforcement must be protected, and no individual or authority should be a judge.

For years, there has been talk of absolute or relative separation of powers. Since human history has been accompanied by the abuse of state power by its rulers, people have sought to limit the authority of their rulers to prevent the use of power by suppressing the rule of law, since freedom is suppressed. And democracy is not only about the participation of the people in the exercise of sovereignty, but also about the need for people to be protected from the oppression of the rulers and to preserve their lives, property and honor in the light of proper law enforcement. An institutional prediction called "judicial oversight" is evidence of the importance of this issue.

\section{Speech One: Power Separation.}

In the Book of Laws, Plato designated separate groups for the rule of law and for the protection of law, the affairs of the city and the administration of justice. Aristotle also states in the book of politics that each government has three powers: the first power is a delegation whose task is to discuss the public interest, the second power is about the rulers and the extent of their jurisdiction and manner of election, and the third power. It also includes the proceedings. This explanation continued until Montesquieu in the eighteenth century clearly divided his powers into the fourth, sixth and seventh chapters of his book, The Spirit of the Laws, and outlined the duties of each branch, linking each to the other. He also argues that in order for power not to be abused, power organizations must be regulated so that power stops power.

In the relative separation of powers, sometimes referred to as cooperation or association of powers, different governmental forces are linked together by legal and political arrangements and, in the course of this distinction, chart the whole of national sovereignty.

The "anti-federalists" believed that in the absolute separation of powers, no branch should exercise more than the triple functions of 
government, and the powers of the powers should be clearly separated. In contrast, proponents of the theory of relative separation of powers considered separation of powers and functions impossible and undesirable. These scholars, including the Federalists or the founders of the US Constitution, found it more appropriate to direct the threepronged power relations known as the "Monitoring and Balance" system. In such a system, the relations of power are regulated in such a way that, despite the more or less clear separation of duties and powers, each force has the means of controlling and moderating the other. Proponents of this system, in fact, differentiate between the concept of "surveillance" and "interference".

To get to the core of the issue, we first discuss whether judicial independence is structural autonomy or is it independent of the judge's personality?

\section{Speech Two: Institutional}

Independence of the Judiciary or Independence of the Judge

The judge should be independent in the handling and issuing of judgments, appeals, appeals, resolving hostilities, resolving hostilities, finding and prosecuting offenders, and punishing offenders and enforcing regulations. Because the heavy task of judging is left to him. So it must have the independence and immunity to carry out this mission without fear, fear, and submission to threats and embarrassment, and the exercise of power and reasoning.

In rule-of-law systems, independent and experienced judges are the basis of a constitutional, fair, impartial and guaranteed constitutional court system known as the judiciary. This independence does not mean that judges can make decisions based on personal preferences, but they are free to make decisions according to the law.

On the other hand, in some systems, such as Kamen Low, the President's political influence on the choice of judicial candidate is to undermine the power of the judiciary, and in the United States based on a system of supervision and balance between political powers, the idea of power seizure by power. And there is widespread judicial oversight of US courts over the functioning of the executive branch. This makes the issue 
of ensuring judicial independence with judicial oversight more sensitive.

\section{Paragraph 1: The concept of judicial control}

\section{Judicial control generally} means the control of the legislature, and the exercise of executive power, such as by-laws and bylaws, by the independent judiciary. What matters is the identification, recognition, and work of the "supreme law" or "supreme law" as well as the supreme law-based judicial control of the US legal system. But what is worth noting in the discussion of the concept of judicial control is the emphasis on the concept of judicial control as a concept, a theory, and a means of bringing the practices and approvals of state powers into 'superior law'. The term "judicial control" is more commonly used in connection with "judicial control of laws". The explanation is that judicial control should not be confused with other types of control, such as administrative control, parliamentary control, and political control.

On the other hand, it should be borne in mind that judicial control has different functions in different systems.
In the United Kingdom, for example, the jurisdiction of the courts for annulment of unlawful acts of the executive branch has been recognized as "constitution" without reference to a text or document. In the UK, issues such as the "legality of government appointments" are being investigated by independent judges. In this country, as in many CIS countries, such disputes are handled in ordinary courts. Although many lawsuits must be brought before special courts (administrative courts), these courts, in turn, are under the control of ordinary courts. That is, "the jurisdiction of the courts to control the conformity of ordinary law and the decisions of the executive branch with the constitution."

In the United Kingdom, judicial control is referred to as "the control of administrative action by the courts on the basis of whether the action is within the jurisdiction of a local authority or a minister." In this sense, judicial control is "a matter of administrative law rather than of fundamental rights".

Judicial control here means the judicial oversight of the approvals of government forces in terms of their compliance with the constitution. This 
special task has been entrusted to special courts in the German Roman Empire under the name of the Constitutional Court.

\section{Paragraph 2: Territory and Principles of Judicial Control}

One of the controversial issues regarding judicial control, territory or scope of this type of control over the exercise of governmental powers. However, this issue is related to other issues such as the power relations and the quality of the exercise of the principle of separation of powers. The main criticism is the principle of judicial control, control, and possibly revocation of legislative approvals and consequently its undemocratic. The question is, in fact, how to justify judicial control when it undermines democratic legislative goals?

Opposition to the principle that the principle of judicial control is democratic, the courts must be democratically accountable, respectful of their laws and avoid judicial review of the views of legislators or members of the executive branch of the judiciary.

In contrast, advocates of the democratic nature of judicial control emphasize the "weakness of the democratic process" as well as "the dangers of relying solely on parliament to effectively defend civil liberties." One of the main arguments presented is that being elected by parliamentarians does not mean total representation of public opinion. On the other hand, it is not always possible to expect the democratically elected people to act loyally. If there was such assurance, there would be no democratic justification for judicial control. But since some elected officials have always said they are trying to legitimize some selfish and biased acts in the name of the people, the judiciary plays an important role in the democratic system.

The second argument for judicial control is the use of "principles". In Durkin's view, judicial control of the law can be justified as "an effective procedure for defending fundamental rights." In his view, "democracy does not insist on the judges having the last word, but it does not insist that the last word not be with them."

In this way, democracy can be assured while recognizing the jurisdiction of the courts for the judicial guarantee of fundamental rights and 
freedoms. On the other hand, one cannot rely solely on the recognition of mere rights and freedoms in the constitution, its constitutional application to the procedures adopted by the state forces, as well as the guarantee of fundamental rights and freedoms, as the constitutional principles are not "self-explanatory"; Meaning that the constitution does not disclose its principles, ambiguities, and inadequacies, but requires another interpretative reference. Nor are the rights enshrined in the Basic Law "selfdetermining", so recognizing their scope and scope of law and the scope of rights are controversial issues that require competent authority to determine their position in disputed positions and that of the independent judiciary. Is.

\section{Paragraph 3: Models of Judicial} Oversight

There are two types of segmentation of judicial oversight models that we will discuss in a variety of different legal systems:

\section{1) Judicial Oversight Models}

\section{Based on Structure Criteria}

According to the structural criteria, what is the basis of the separation is the dependence and position of the institutional structure that oversees it. Thus, according to the systems in the legal system, two main models and one sub-model can be identified, the two main models being the French model and the Engels model. The German model can also be considered as a sub-model.

A) French or intramural model In the French model, government control is exercised by a body within the body itself. As such, neither the legislature nor the judiciary can nullify or respond to the acts of the executive branch. The French interpretation of the principle of separation of powers is based on the assumption that the main meaning of separation of powers is the noninterference of the judiciary in the affairs of the executive branch.

B) English model or decentralized model

This model, which is followed in most English-speaking countries, is exactly the opposite of the French model. The Communo Law model is a decentralized model in which courts can hear administrative decisions. The intellectual basis of this model is to be found in the judicial history of 
England. Kamen Law's judicial approach is based on the existence of powerful, independent courts, and its entire legal system is more than legally obliged and independent of the judiciary and judges.

(C) German model or integrated model

The German model can be seen as a combination of both French and English. In this model, administrative courts are formed within the judiciary, but their structure is completely separate from that of ordinary courts. Judicial oversight in Germany, Japan, etc. is based on this model. This model has somehow tried to exploit some of the benefits of both systems. Examples include:

It is generally said that an English judge, because he is not an administrative person himself, cannot understand the sensitivities of the office and therefore will not be able to issue a correct opinion in the administrative case. However, the office does not personally deal with the lawsuit itself. As such, one of the basic principles of procedural justice that no one can judge is their own lawsuit. In the German model, this principle has been tried to be complied with, and therefore the administrative courts have been governed by the judiciary.

\section{2) Separation of jurisdictional models} based on jurisdiction

By jurisdiction, judicial oversight patterns can be divided into two general Anglo-Saxon and RomanGerman categories. The basis of the separation can be called the scope of supervision. In the Anglo-Saxon paradigm, due to the overwhelming focus of the court's focus, judges are of great importance and dignity. On the other hand, according to traditional and dominant thinking in this country, the king is equal to the other in legal rules. Therefore, lawsuits against the king and his agents are handled in the courts by rules that apply to the public. Accordingly, in English-speaking countries that generally use Communalstyle judicial oversight, the courts that deal with the public are the same courts that deal with the government.

As a second feature, in the Commonwealth countries, judicial oversight authorities also have the power to exercise oversight over the laws of parliament. Thus, in most of the Commonwealth countries, the courts of 
the judiciary can both hear lawsuits against the executive branch and lawsuits that are contrary to the constitution. In the United States, for example, the court may refuse to enforce a law that is contrary to the constitution, which is "unconstitutional."

Contrary to what is happening in the Communist system, in the Roman-German system, neither the judiciary nor the executive authorities can overturn the laws adopted by parliament. In fact, from this point of view, overseeing the exercise of office is very different in content and structure from overseeing the legitimacy of laws. Usually, in these countries, a political entity called the Constitutional Court generally decides on this issue. In France, for example, the Constitutional Council and in Iran the Guardian Council deal with this.

One point that can be made in response to the claim that the judiciary is undemocratic is that democracy does not simply mean majority rule, but sociopolitical military democracy in which the system recognizes and builds fundamental human rights and governance and Provides their assurance work. In this sense of democracy,
501

independent judges guarantee the protection of human rights and freedoms and the undeniable principles of democracy and do not seek to preserve the will, the temporality and the emotions of the majority or the desires and goals of the dominant political parties.

\section{Speech Three: Maintaining the} Independence of the Judiciary with Judicial Oversight

Government oversight and performance has a very short history. Compared to the hundreds of thousands of years of political power, it is only in recent centuries that signs of such concepts as rule of law, accountable government and government oversight can be seen. The foregoing concepts emerged only when there was a profound change in some issues. The path through which the slave became a citizen should be a turning point in the history of judicial oversight.

Hobbes, Body, Locke, and Montesquieu, philosophers of the Enlightenment, each presented their own plan of separation of powers. Although different models were offered by these individuals, the basic principle and main 
purpose of all these models was to confront power by power.

The breakdown of absolute power into smaller powers that were confronted, in part, was able to reduce the sharpness of the pre-existing natural and state differences between the state and the citizen. With the relative shift of this divide, as it was said, the three branches of government were confronted. By conferring the intrinsic competence of each of these three powers, they were obliged not to exceed their limits. The central axis of this distinction was Montesquieu's law, thus separating the three powers. The authority that enacted the law; the authority that enforced the law, and ultimately the authority that oversaw the implementation of the law.

The first example of the monitoring of government actions can be seen in France and in the history of the State Council. The reason for the above oversight is to ensure that the government does not act in violation of the laws of the parliament in order to undermine the rights of citizens.

In any case, the first experiences of overseeing the conduct of government should be found in the
Communist system and in the United Kingdom. The same system gave the authority to the independent judges to deal with both administrative and private cases equally with the government and the public. In the Communist system, there has long been no distinction between private and public law. Daisy, the greatest British lawyer, argued that there should be no distinction between government and people rights.

According to Kelly, it was for the first time in France in the 1760s that a group of Enlightenment writers who were known as "physiocrats" and focused their attention on economics claimed that judges had to go before law enforcement. Ensure their true conformity with the "laws of the natural law of the social system" and "justice". The concept of "supervision and balance" was first spoken in England in the seventeenth century. Harrington in 1656 believed that the rule of law required a real balance between the powers that be able to control one another. John Locke is also the first theoretician to point out that the constitution is based on a system of monitoring and balance.

\section{Conclusion}


Judicial control is the main mechanism of government restraint exercised by independent judges in the powerful judiciary. In most countries, despite the prevalence of diverse political and legal systems, judicial control over legislative approvals and executive decisions and regulations has been accepted. The importance of judicial control in democratic systems is the product of the thinking that holds the courts at the core of the rule of law. Courts are seen as an institution that should play a role in balancing the efficiency and speed of executive power and the need to defend citizenship against arbitrary rule, thereby demonstrating their independence in the proceedings.

The above belief is based on a series of assumptions upon which the entire Communal Law system is based. The authority of the judiciary can be one of these assumptions. The power of the judiciary in this country is the result of its political history. While the French judges were blocking the way for administrative reform in that country, the English judges of the parliament of that country formed a coalition against the Shah as a symbol of the power that was later called the executive branch, which led to a "glorious revolution". This record of cooperation was enough to establish the position of English judges as national champions. While the history of the French magistrates had turned them into thugs who had to be ousted by the revolutionaries.

\section{References}

Akhundi, Mahmoud, Independence of Judges in the Iranian Legal System, Law Journal of Justice, no. 24.

Akhundi, Mahmoud, Unauthorized Judge, Ettela'at daily, November 18 and 25, 1995 and Thursday, December 1995.

Akhundi, Mahmood; The Criminal Procedure Code, Tehran, Printing and Publishing Organization, 2009, Fourteenth Edition, Volume I.

Relaxation, Prophet, Thought: Legal Pathology: Independence of Judge and Judiciary, Lawyer, Bahman \& Esfand 2001, No. 9, p. 18.

Mr Tawak, The Principles and the Nature of Judicial Oversight of Government Acts: A Comparative Study 
of the Countries of France, England and the United States, Journal of Legal Research, Winter 2007, no. 1, pages 125192.

Aghaei Togh, Moslem, "Investigating and Evaluating the Origins of the Legal System Theory", Journal of Fundamental Rights, No. 7-6, 2006.

Wat Jones, Gods of Political Thought, translated by Ali Ramin, Amir Kabir Publishing Institute, 1979.

Zarei, Mohammad Hossein, "Good Governance, Sovereignty and Governance in Iran", Journal of Legal Research, No. 40, Fall-Winter 2004, pp. 202-155.

Zarei, Mohammad Hussein, Malmiri Center, Ahmad, The Concept and Principles of Judicial Control with Emphasis on the United States Legal System, Journal of Legal Research, Fall and Winter 2005, No. 42, pp. 149 to 198.

Fawadi, Siavash, on the Independence of the Judiciary or Cooperation with the Judiciary on Attitude to the Judiciary,
Bar Association Journal, Fall and Winter 2008, Nos. 202 and 203. Judge, Abu al-Fazl, Fundamental Rights and Political Institutions, Volume I, Tehran University Press, 1991.

Good Faith, Mohammad Reza, A Critique of Federalism, Tehran: Shiraz, 1998.

Madani, Seyyed Jalaluddin, The Fundamental Rights and Political Institutions of the Islamic Republic of Iran, Associated Press, 1991.

Mehrpour, The Judges' Stand Up for Independence, the subject of Article 164 of the Constitution, Journal of Judgment, December and December 2010 - No. 67, p. 39.

Kelly, John Morris, A Brief History of Legal Theory in the West, Translated by Mohammad Rasekh, Tehran: A New Design, 2003

Hashemi, Seyyed Mohammad, Human Rights and Fundamental Freedoms, Publication No. 2005. 
Rehnquist, W. "Remarks of the chief justice, Washington college of law, continental celebration plenary academic panel": the future of the federal courts. (speech).(1996) .

Aranson, P.H. " Judical Review ", in Newman, P. (ed) , The Palgrave Dictionary of Economics and Law, Vol. 2, (London: Macmillian Refrence Limited,1998) .

H.W.R. Wade and L.F. Forsyth, Administrative Law, ( Oxford: Clarendon Press,1994).

Barendt, E. An Introduction to Cons titutional Law,( Oxford: Oxford University Press,1998).

Elliott, C. and Quinn, F. English Legal System, (London:Longman,2000) , pp. 443-438;

Le Sueur, A. Public Law, (London:Longman,1997), pp. 705-680; Carrol, A. Condtitutional \& Administrati ve Law, ( Edinburg:Pitman Publishing, 1998), Part. 5.
Holemes.S. "Costitutionalism",in Lipset, S.M. ( ed.) , The Encyclopedia of Democracy,( London:Rutledge, 1995).

Dworkin ,R. " Introduction ;The Moral Reading and the Majoritarian Prenise " , in Freedom's Law,( Oxford: Oxford University Press,1996).

Robert

A.Goldwin.R.A kaufman.A(eds)(1986).» Enterprise Institute for Policy Reesearch,p.ix Separation of Powers,Does lt Still Work?,WashingtonAmerican

Cambridge University Press,p.82 Montesquieu.C(1989), The Spirit of Laws,Cambridge:

Yale law Journal,p.p.502-505 Bilder.M.S(2006), The Corporate Origins of Judicial Review

Bilder.M.S(2007)Why We Have Judicial Review,Yale Law Journal,p.p.215-216P

Dicey.A.V(1897),An introduction To Study of The Law of The Constitution, London:Macmillan,p.323.

Dicey, A. V. An Introduction to the Law of the Constitution, Published 
Periódico do Núcleo de Estudos e Pesquisas sobre Gênero e Direito

Centro de Ciências Jurídicas - Universidade Federal da Paraíba V. 9 - $\mathrm{N}^{\circ} 02$ - Ano 2020

ISSN | 2179-7137 | http://periodicos.ufpb.br/ojs2/index.php/ged/index

in 1885,10 th edn. edited byWade, E. C

$. S,(1959)$ 